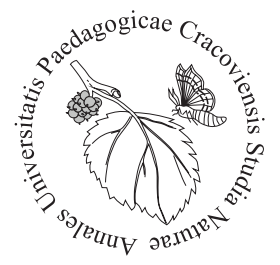

Samuel Robinson', William Cetzal-IX², Saikat Kumar Basu*

${ }^{1}$ Department of Biological Sciences, University of Calgary, Alberta, Canada

${ }^{2}$ Instituto Tecnológico de Chiná, Tecnológico Nacional de México, Chiná, Campeche, Mexico

${ }^{3}$ Department of Biological Sciences, University of Lethbridge, Alberta, Canada, *saikat.basu@alumni.uleth.ca

\title{
Wild bee decline and conservation in North America
}

\section{Pollination by wild bees}

One of the major challenges of the $21^{\text {st }}$ century will be feeding an increasing number of people on smaller and smaller areas of fertile land. While much of our diet comes from crops which do not require any animal pollination (e.g., wheat, corn, rice), about 35\% of global food production depends on pollinating animals, such as bees (Klein et al., 2007). Over $90 \%$ of the vitamin C in our diet - as well as a majority of other vitamins, minerals, antioxidants, and micronutrients - come from animal-pollinated crops (Eilers et al., 2011). This makes animal pollinators an important part of the human food supply and global economy, and conservation of pollinators will be a key factor in managing global food security.

Historically, most pollination worldwide has been done by wild bees, and in most undeveloped nations, a majority of pollination is still done by wild pollinators (flies, moths, butterflies, bats, and hummingbirds also provide some services). However, developed nations typically rely on large-scale pollination services provided by the European honey bee, Apis mellifera L. Honey bees were brought to North America by European settlers, and they have expanded into a multi-billion dollar industry over the last 50 years. The total value of pollination services worldwide is close to $\$ 178$ billion USD (Gallai et al., 2009). In the United States in 2009, the total value of crop pollination services from honey bees was $\$ 11.6$ billion, while services from non-honey bees were about $\$ 3.4$ billion, with much of this value coming from almond, apple, and sunflower crops, which are all highly pollinator-dependent and grown in large amounts (Calderone, 2012).

While much of the general public are aware of honey bees and bumble bees in North America, they are often surprised to find out that this is a tiny fraction of the total number of bees! Out of the 20.000 species of bees worldwide, there are about 4600 


\begin{tabular}{|c|c|c|c|}
\hline Family & $\begin{array}{l}\text { Number } \\
\text { of genera }\end{array}$ & $\begin{array}{l}\text { Number } \\
\text { of species }\end{array}$ & Examples \\
\hline Andrenidae & 12 & 1472 & $\begin{array}{l}\text { Mining bee (Andrena sp., Panurgus sp.) } \\
\text { Fairy bee (Perdita sp.) } \\
\text { Squash bees (Peponapis sp.) }\end{array}$ \\
\hline Apidae & 83 & 1305 & $\begin{array}{l}\text { Honey bee (Apis mellifera) } \\
\text { Bumble bee (Bombus sp.) } \\
\text { Long-horned bees (Eucera sp., Mellisodes sp.) } \\
\text { Carpenter bees (Xylocopa sp.) } \\
\text { Stingless bees (Melipona sp., Trigona sp.) }\end{array}$ \\
\hline Colletidae & 9 & 288 & Cellophane bee (Colletes sp., Hylaeus sp.) \\
\hline Halictidae & 26 & 654 & $\begin{array}{l}\text { Sweat bee (Halictus sp., Lasioglossum sp.) } \\
\text { Green bee (Agapostemon sp., Augochlora sp.) }\end{array}$ \\
\hline Megachilidae & 26 & 791 & $\begin{array}{l}\text { Leafcutter bee (Megachile sp.) } \\
\text { Mason bee (Osmia sp.) } \\
\text { Carder bee (Anthidium sp.) }\end{array}$ \\
\hline Mellitidae & 3 & 28 & Mellita sp., Macropis sp. \\
\hline
\end{tabular}

species of bees living in North America (Ascher, Pickering, 2017) (Tab. 1, Appendix - Fig. 1-2), and most of them are in the desert southwest of the United States (Wilson, Carril, 2016). This is mainly due to the local diversity of local flowering plants, as high flowering plant diversity generally translates into higher bee diversity (Potts et al., 2003). There are 46 species of bumblebee living in North America (Williams et al., 2014), but most wild bees are solitary. Solitary bees do not have a strict caste system with workers, queens, and drones, and can live their lives independently from each other. However, many 'solitary' bees will start acting socially (guarding nests, feeding other bees larvae, acting as queens and workers) if enough of them are in the same area (Williams et al., 2014).

\section{Pollinator decline}

Are wild bee populations declining? Because of their large diversity, difficulties in identifying them, and the fact that they are not as well-known as honey bees, they are less well-sampled in North America, and even less so in Mexico (Freitas et al., 2009). Historical insect collections have proved to be valuable sources of information, as we can compare 'snapshots' of bee populations through time at a given location. Unfortunately, this has revealed that many wild bee populations are in decline. Cameron et al. (2011) used over 73.000 museum specimens to study 8 common species of bumblebees across the continental US, and found that 4 out of 8 were in serious decline. The International Union for Conservation of Nature (IUCN) lists 12 out of 37 North American bumble bees (that we have good data for) as being endangered or vulnera- 
ble (IUCN, 2017). Solitary bees do not fare much better in this regard. Biesmeijer et al. (2006) found that there have been declines in wild bee populations across Britain and the Netherlands, and more worryingly, there have also been declines in the plants that are pollinated by these bees!

\section{Causes of decline}

The factors that contribute to the decline of wild bees can also be complex, but there are some general drivers of pollinator decline:

\section{Land use changes}

Globally, about $40 \%$ of land has been converted to agricultural land (Foley et al., 2005). In Mexico, large-scale deforestation for charcoal, cattle, or agricultural expansion has reduced native rainforests to almost $10 \%$ of their original extent (Freitas et al., 2009). More than $50 \%$ of North American grasslands have been converted to agriculture (Hoekstra et al., 2005), and in some parts of western North America, this number approaches almost 100\%, especially for tall-grass prairie (Samson et al., 1998).

Habitat destruction has 2 main effects on wild bee populations: the reduction of food sources (flowers) and the reduction of nest sites. Wind-pollinated crops, such as corn, provide little nutrition for bees, and even crops like canola or alfalfa (which bees can benefit from) can be unhelpful in the long run, as the flowers are only available during a few weeks of the summer. Some bee species are only active for a few weeks during the summer, so if their foraging time does not overlap with the flowering of the crop, they have no food!

Crop fields can be dangerous for bees, as tillage and irrigation can destroy nest sites in the ground, and pesticides can injure or confuse bees. Agricultural areas typically have few species of flowering plants present, meaning that generalist bees can persist (Kleijn et al., 2015), but that floral specialists will be without the flowers that they need. Finally, crop fields in the US and Canada are often very large; small bees often only have flight ranges of a few hundred yards, meaning that finding areas with both nest habitat and food becomes more and more difficult as fields get bigger and bigger.

\section{Honey bees}

Honey bees, while being incredibly useful and profitable for humans, can put pressure on wild bee populations. They do this in two ways: competition for flowering plants, and disease spillover. Honey bee colonies can raise 150-200.000 bees per year (Seeley, 1985), and the sheer number of foraging workers can drain nectar and pollen resources around their hives. They can also fly up to $5 \mathrm{~km}$ while foraging, while many solitary 
bees only fly a few hundred meters during their entire lifetime, meaning that honey bees have the potential to compete with many types of wild bees. In Mexico, stingless bees (Melipona beecheii Bennett) can be directly attacked by Africanised honey bees, and declines in native Mayan beekeeping over the last 20 years have been associated with increases in numbers of honey bees (Cairns et al., 2005). Many bumblebee diseases are similar to those of honey bees, meaning that disease spillover can occur between them. For example, Fürst et al. (2014) found that both Nosema ceranae I. Fr., F. Feng, J.A. da Silva, S.B. Slemenda \& N.J. Pieniazek and deformed wing virus (2 diseases of honey bees) could easily reproduce in bumblebee colonies, and more worryingly, both diseases were found in wild populations of bumblebees across the United Kingdom. Diseases of solitary bees are not well-studied, but chalkbrood fungus from honey bees (Ascosphaera aggregata Skou) can also infect leafcutter bees (Goulson, 2003). Finally, beekeepers provide help to honey bees by controlling their pests and diseases, and by feeding them during flower-free periods. This make sense, given that their livelihoods are based on having a large worker force, but this can put wild bees at a distinct disadvantage when it comes to surviving alongside honey bees.

\section{Insecticides}

Large amounts of attention have been devoted to the effect of pesticides on honey bees. In particular, neonicotinoid insecticides have been implicated in honey bee deaths. There is far less data examining the effects of pesticides on wild bees, but research does show that insecticides can change foraging behaviour and can cause increased rates of mortality in bumblebees. For example, Laycock et al. (2014) found that bumblebees fed small amounts of pesticides in their diet tended to live shorter lives. Sandrock et al. (2014) showed that mason bees (Osmia bicornis L.) can also be affected, as they tended to produce less offspring when fed small doses of pesticides throughout their lives. However, it is far less clear whether these small-scale effects of pesticides are causing reductions in wild bee populations, and it is more likely that a combination of land use changes, diet changes, and pesticide usage are driving declines in wild bee populations (Goulson et al., 2015).

\section{Mitigation}

Clearly, there are many things that threaten the existence of wild bee populations. But how can we help encourage robust wild bee populations, and lessen risks of extinction? Even more importantly, how do we balance our desire for agriculture and urban development while still conserving wild bees? To do this, we need to move beyond the "only honey bees" mentality. We suggest that both individuals and local governments should work to establish wild bee habitats in order to preserve local species diversity and abundance. 
While we recognise that honey bees are extremely practical in the modern agricultural setting, we encourage people to begin thinking beyond just honey bees, and to consider wild pollinators as valuable parts of our ecosystems. Worldwide, the number of pollinator-dependent crops have grown more than $300 \%$ in the last 50 years, while the number of honey bee colonies has only grown by $45 \%$ (Aizen, Harder, 2009). This means that the number of honey bees has not kept pace with our growing demand for pollination, and this 'pollination gap' will continue to increase into the future. Wild pollinators also provide insurance against honey bee die-offs, which have increased in severity in many parts of the United States. Additionally, honey bees are not necessarily the best pollinators for all crops!

Garibaldi et al. (2013) found that in over 41 worldwide crop types, wild pollinators increased yield across all fruit, nut, and seed crop types, but that honey bees only increased yield in $14 \%$ of the crop types. In other words, honey bees can supplement, but not replace, pollination by wild pollinators. Greenleaf and Kremen (2006) found that the yield of hybrids sunflowers was increased in fields located close to natural areas, and that honey bees switched between flowers more frequently if there were wild bees present, meaning that wild bees can actually increase the efficiency of honey bee pollination! In this way, wild pollinators have the potential to work alongside introduced pollinators if they establish stable populations.

Bee habitats should provide a diverse set of food resources and stable year-toyear nesting sites for wild pollinators. These areas can extend the bee foraging period beyond the flowering crop season (Basu, Cetzal-Ix, 2017) and provide undisturbed nesting sites so that populations can more easily persist from year-to-year. Plant seed mixtures could include native wildflowers, grasses, and legumes, as well as flowering trees and shrubs. Priority should be given to native plants, as they generally benefit wild pollinators more than introduced plant species. The plant species included in the mixture should be selected so that they do not all flower simultaneously, but are spread across the flowering season so that they benefit the widest range of pollinators (Basu, Cetzal-Ix, 2017). Hedgerows or other pollinator habitats will need to be tailored specifically for each region in which they are planted, and the Xerces Society (http:// xerces.org/guidelines/) provides recommendations for planting pollinator habitats, including lists of plant species across the continental United States and Canada.

But will creating new pollinator habitats take away farmland or urban areas and create 'off-limit' zones for human development or activity? Not necessarily, because many unused areas already exist in urban and rural environments where these pollinator habitats could be established. Habitats could be established along fence lines, wind breaks, irrigation canals, highways, sections of golf courses, and municipal parks and gardens (Basu, 2017; Basu, Cetzal-Ix, 2017). Pollinator habitats can have positive impacts on the richness and abundance of wild bee species, and they can provide 
benefits to farmers growing pollinator-dependent crops. For instance, Kremen and M'Gonigle (2015) found that planting hedgerows (lines of flowering shrubs and bushes) in the highly cultivated Napa Valley in California increased the abundance of both common and rare pollinators. Not only did these hedgerows increase abundance and diversity locally, but they acted as sources of wild pollinators for the surrounding adjacent fields, as fields planted next to hedgerows tended to have higher numbers of pollinators present in them (Morandin, Kremen, 2013). Even within highly disturbed agricultural or urban areas, there is still hope for wild pollinators!

\section{Acknowledgements}

WCI would like to acknowledge the support from TecNM Project (CHN-LGAC-03-14) "Caracterización de la flora nativa de importancia apícola en Campeche: estrategia para incrementar la productividad en las colonias de abejas melíferas en periodos críticos de floración". Research assistance and funding provided to SKB by Performance Seed, Lethbridge, AB, Canada for developing different Performa Pollinator Mixes (comprising of annual/perennial legumes, wildflowers, and grasses) is gratefully acknowledged.

\section{References}

Aizen, M.A., Harder, L.D. (2009). The global stock of domesticated honey bees is growing slower than agricultural demand for pollination. Current Biology, 19(11), 915-918. DOI: 10.1016/j.cub.2009.0371

Ascher, J., Pickering, J. (2017). Discover Life bee species guide and world checklist. http://www.discoverlife.org $/ \mathrm{mp} / 20 \mathrm{q}$ ?guide=Apoidea_species\&flags=HAS.

Basu, S. (2017). Proposed bee conservation and apiculture promotion initiatives for South Asia. NESA Newsletter, 20, 2-4.

Basu, S., Cetzal-Ix, W. (2017). Establishing bee sanctuaries in North America for conserving insect pollinators with special emphasis to native bees. International Journal of Agricultural Science, 8(1), 1-8.

Biesmeijer, J.C., Roberts, S.P.M., Reemer, M., Ohlemüller, R., Edwards, M., Peeters, T., Schaffers, A.P., Potts, S.G., Kleukers, R., Thomas, C.D., Settele, J., Kunin, W.E. (2006). Parallel declines in pollinators and insect-pollinated plants in Britain and the Netherlands. Science, 313(5785), 351-354. DOI: $10.1126 /$ science. 1127863

Cairns, C.E., Villanueva-Gutiérrez, R., Koptur, S., Bray, D.B. (2005). Bee populations, forest disturbance, and Africanization in Mexico. Biotropica, 37(4), 686-692. DOI: 10.1111/j.1744-7429.2005.00087.x

Calderone, N.W. (2012). Insect pollinated crops, insect pollinators and US agriculture: Trend analysis of aggregate data for the period 1992-2009. Plos One, 7(5), 1-27. DOI: 10.1371/journal.pone.0037235

Cameron, S.A., Lozier, J.D., Strange, J.P., Koch, J.B., Cordes, N., Solter, L.F., Griswold, T.L., Robinson, G.E. (2011). Patterns of widespread decline in North American bumble bees. Proceedings of the National Academy of Sciences of the United States of America, 108(2), 662-667. DOI: 10.1073/pnas.1014743108

Eilers, E.J., Kremen, C., Greenleaf, S.S., Garber, A.K., Klein, A.-M. (2011). Contribution of pollinator-mediated crops to nutrients in the human food supply. Plos One, 6(6), e21363. DOI: 10.1371/journal. pone. 0021363

Ellis, J.D., Evans, J.D., Pettis, J. (2010). Colony losses, managed colony population decline, and colony collapse disorder in the United States. Journal of Apicultural Research, 49(1), 134-136. DOI: 10.3896/ IBRA.1.49.1.30

Foley, J.A., DeFries, R., Asner, G.P., Barford, C., Bonan, G., Carpenter, S.R., Chapin, F.S., Coe, M.T., Daily, G.C., Gibbs, H.K., Helkowski, J.H., Holloway, T., Howard, E.A., Kucharik, C.J., Monfreda, C., Patz, J.A., Prentice, I.C., Ramankutty, N., Snyder, P.K. (2005). Global consequences of land use. Science, 309(5734), 570-574. DOI: 10.1126/science. 1111772 
Freitas, B.M., Imperatriz-Fonseca, V.L., Medina, L.M., Kleinert, A.D.M.P., Galetto, L., Nates-Parra, G., Quezada-Euán, J.J.G. (2009). Diversity, threats and conservation of native bees in the neotropics. Apidologie, 40(3), 332-346. DOI: 10.1051/apido/2009012

Fürst, M., McMahon, D., Osborne, J., Paxton, R., Brown, M. (2014). Disease associations between honeybees and bumblebees as a threat to wild pollinators. Nature, 506(7488), 364-366. DOI: 10.1038/ nature12977

Gallai, N., Salles, J.-M., Settele, J., Vaissière, B.E. (2009). Economic valuation of the vulnerability of world agriculture confronted with pollinator decline. Ecological Economics, 68(3), 810-821. DOI: 10.1016/j. ecolecon.2008.06.014

Garibaldi, L.A., Steffan-Dewenter, I., Winfree, R., Aizen, M.A., Bommarco, R., Cunningham, S.A., Kremen, C., Carvalheiro, L.G., Harder, L.D., Afik, O. (2013). Wild pollinators enhance fruit set of crops regardless of honey bee abundance. Science, 339(6127), 1608-1611. DOI: 10.1126/science. 1230200

Goulson, D. (2003). Effects of introduced bees on native ecosystems. Annual Review of Ecology, Evolution, and Systematics, 34(1), 1-26. DOI: 10.1146/annurev.ecolsys.34.011802.132355

Goulson, D., Nicholls, E., Botías, C., and Rotheray, E.L. (2015). Bee declines driven by combined stress from parasites, pesticides, and lack of flowers. Science, 347(6229), 1435. DOI: 10.1126/science. 1255957

Greenleaf, S.S., Kremen, C. (2006). Wild bees enhance honey bees' pollination of hybrid sunflower. Proceedings of the National Academy of Sciences, 103(37), 13890-13895. DOI: 10.1073/pnas.0600929103

Hoekstra, J.M., Boucher, T.M., Ricketts, T.H., and Roberts, C. (2005). Confronting a biome crisis: global disparities of habitat loss and protection. Ecology Letters, 8(1), 23-29. DOI: 10.1111/j.14610248.2004.00686.x

IUCN. The International Union for Conservation of Nature (2017). Red List of Threatened Species. Version 2017-1.

Kleijn, D., Winfree, R., Bartomeus, I., Carvalheiro, L.G., Henry, M., Isaacs, R., Klein, A.-M., Kremen, C., M'Gonigle, L.K., Rader, R. (2015). Delivery of crop pollination services is an insufficient argument for wild pollinator conservation. Nature communications, 6, 7414. DOI: 10.1038/ncomms8414

Klein, A.-M., Vaissière, B.E., Cane, J.H., Steffan-Dewenter, I., Cunningham, S.A., Kremen, C., Tscharntke, T. (2007). Importance of pollinators in changing landscapes for world crops. Proceedings of the Royal Society B: Biological Sciences, 274(1608), 303-313. DOI: 10.1098/rspb.2006.3721

Kremen, C., M'Gonigle, L.K. (2015). Small-scale restoration in intensive agricultural landscapes supports more specialized and less mobile pollinator species. Journal of Applied Ecology, 52(3), 602-610. DOI: $10.1111 / 1365-2664.12418$

Laycock, I., Cotterell, K.C., O'Shea-Wheller, T.A., Cresswell, J.E. (2014). Effects of the neonicotinoid pesticide thiamethoxam at field-realistic levels on microcolonies of Bombus terrestris worker bumble bees. Ecotoxicology and Environmental Safety, 100, 153-158. DOI: 10.1016/j.ecoenv.2013.10.027

Morandin, L.A., Kremen, C. (2013). Hedgerow restoration promotes pollinator populations and exports native bees to adjacent fields. Ecological Applications, 23(4), 829-839. DOI: 10.1890/12-1051.1

Potts, S.G., Vulliamy, B., Dafni, A., Ne'eman, G., Willmer, P. (2003). Linking bees and flowers: how do floral communities structure pollinator communities? Ecology, 84(10), 2628-2642. DOI: 10.1890/020136

Samson, F.B., Knopf, F., Ostlie, W. (1998). Grasslands. In: M.J. Mac (ed.), Status and Trends of the Nation's Biological Resources, 2, 437-472.

Sandrock, C., Tanadini, L.G., Pettis, J.S., Biesmeijer, J.C., Potts, S.G., Neumann, P. (2014). Sublethal neonicotinoid insecticide exposure reduces solitary bee reproductive success. Agricultural and Forest Entomology, 16(2), 119-128. DOI: 10.1111/afe.12041 
Seeley, T.D. (1985). Honeybee ecology: a study of adaptation in social life. New Jersey: Princeton University Press.

The Xerces Society for Invertebate Conservation. http://xerces.org/guidelines/

Williams, P.H., Thorp, R.W., Richardson, L.L., Colla, S.R. (2014). Bumble bees of North America: an identification guide. Princeton Field Guides. New Jersey: Princeton University Press.

Wilson, J.S., Carril, O.M. (2016). The bees in your backyard: a guide to North America's bees. New Jersey: Princeton University Press. 

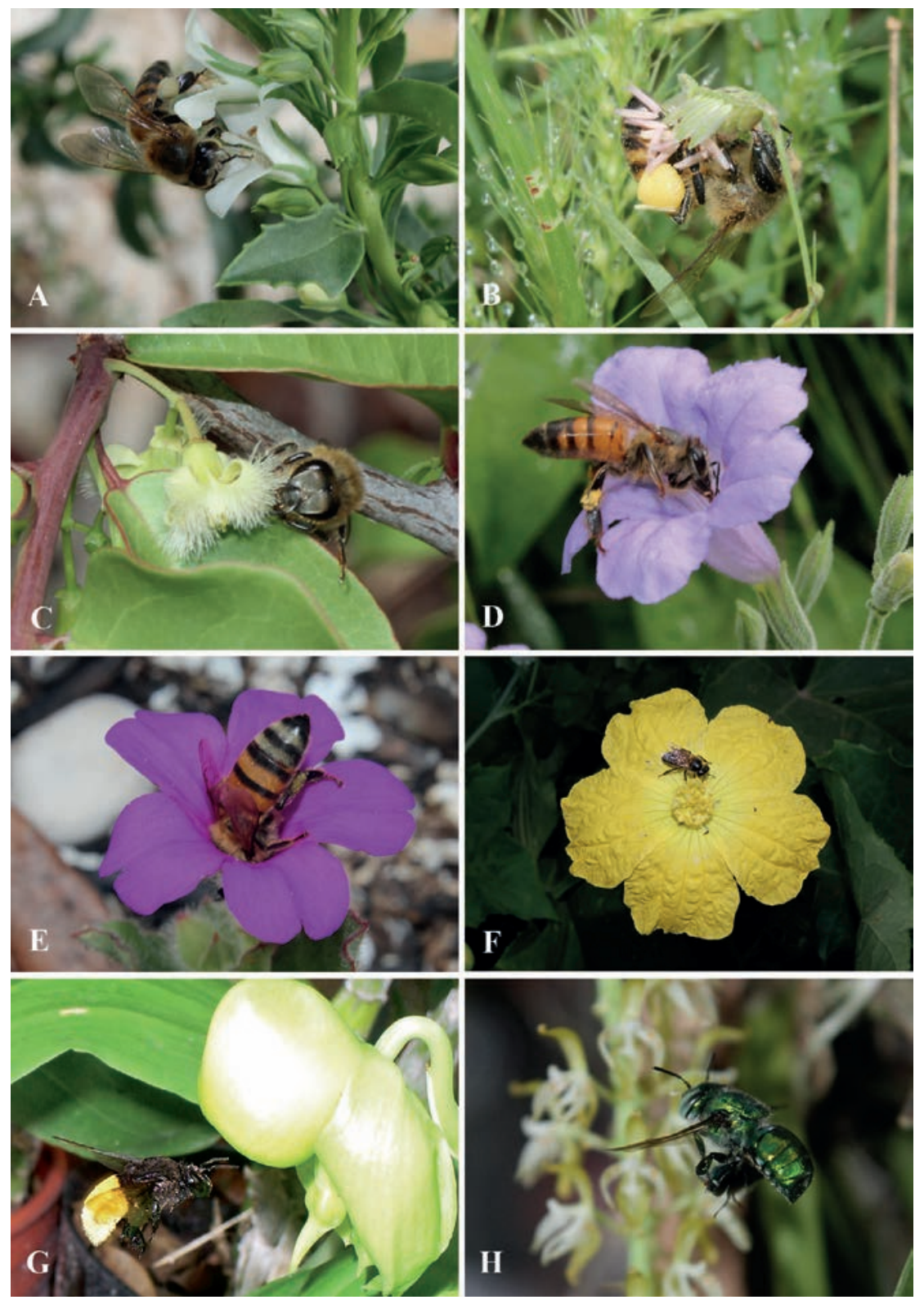

Fig. 1. Diversity of flora of Mexico pollinated by different species of bees.

Bees: A-E - Apis mellifera L., F - Scaptotrigona sp., G - Bombus sp., H - Euglossa viridissima Friese. Plants: A - Capraria mexicana Moric. ex Benth. (Scrophulariaceae)., B - species from the family of grasses (Poaceae), C - Ximenia americana L. (Olacaceae), D - Ruellia nudiflora (Engelm. \& A. Gray) Urb. (Acanthaceae), E - Okenia hypogaea Schltdl. \& Cham. (Nyctaginaceae), F - Luffa aegyptiaca Mill. (Cucurbitaceae), G - Catasetum integerrimum Hook. (Orchidaceae), H - Notylia barkeri Lindl. (Orchidaceae) (Photo. W. Cetzal-Ix) 

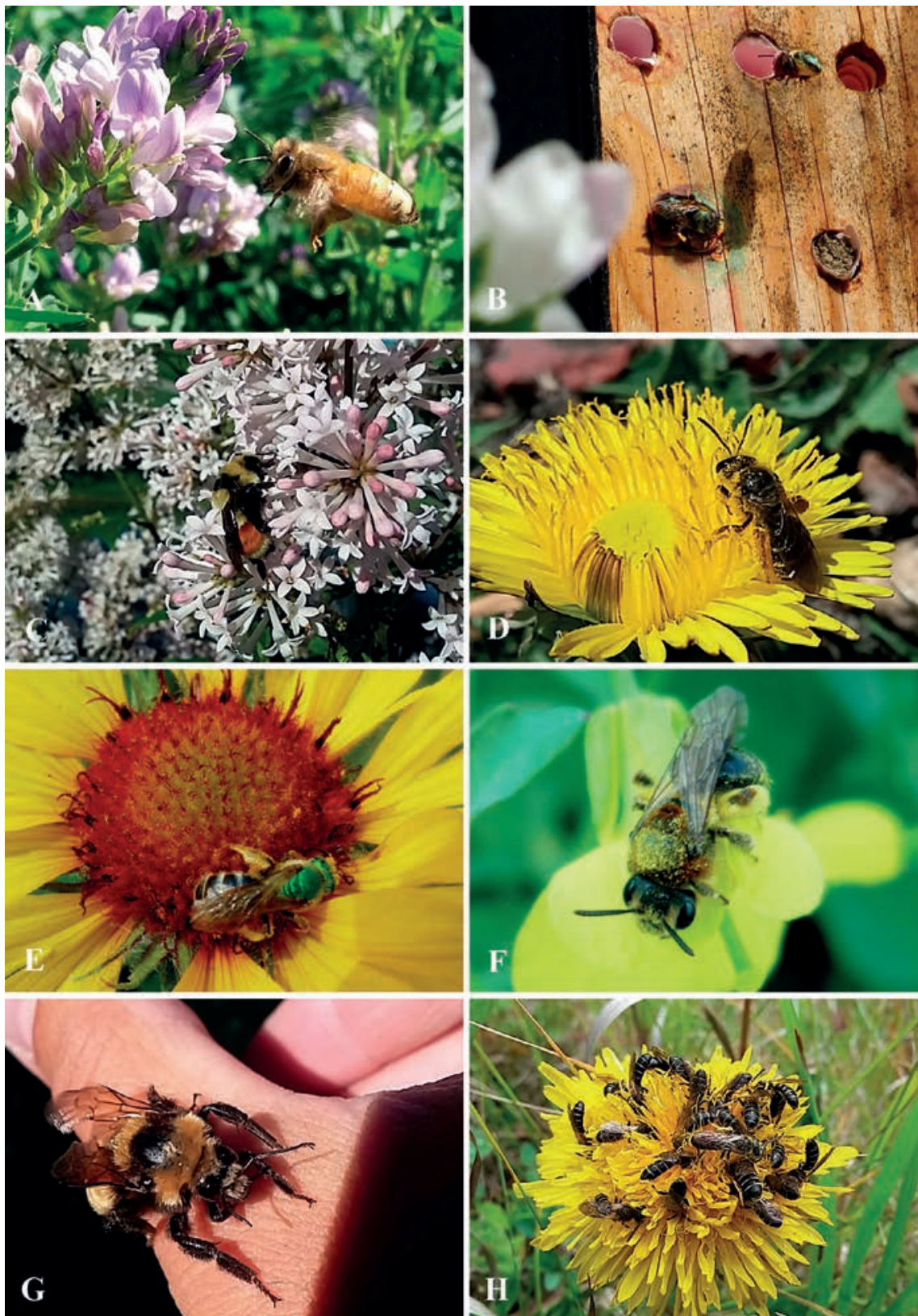

Fig. 2. Some common western North American bee species.

Bees: A - Apis mellifera L., B - Osmia lignaria Say provisioning their nests in a bee block, C - Bombus ternarius Say, D - Halictus sp., E - Agopostemon virescens Abrams \& Eickwort, F - Andrena lupinorum Cockerell, G - Bombus borealis Kirby, $\mathrm{H}$ - Halictus spp.

Plants: A - Medicago sativa L. (Fabaceae), C - Syringa vulgaris L. (Oleaceae), D, H - Taraxicum officinale F. H. Wigg. (Asteraceae), E - Gaillardia aristata Pursh (Asteraceae), F - Brassica napus L. (Brassicaceae) (Photo. S. Robinson and P. Birch) 
Pszczoły - to niezwykle różnorodna i ważna grupa owadów; około 4600 gatunków pszczół występuje w Ameryce Północnej. Dzikie pszczoły „świadczą usługi” w zakresie zapylania roślin, a ich działalność jest prawdopodobnie nawet więcej warta niż działalność pszczół miodnych na całym świecie. Są one słabo zbadane na większości obszarów, ale na terenach, dla których mamy wiarygodne dane, liczebność ich populacji obniża się. Wynika to głównie z przekształcania obszarów półnaturalnych w grunty rolne, a nowsze dane wskazują również, że pszczoły miodne mogą także wpływać na ich populacje. Aby zachować istniejące populacje pszczół, należy ustalić siedliska zapylaczy, w celu zachowania różnorodności dzikich zapylaczy w krajobrazach wiejskich i miejskich. W miarę jak populacja ludzi rośnie wraz z zapotrzebowaniem na produkcję rolną, musimy znaleźć sposoby „współpracy” z dzikimi zapylaczami i sposoby zachowania dla przyszłych pokoleń tysięcy gatunków pszczół, które żyją w Ameryce Północnej i w innych częściach świata.

Key words: causes of decline, conservation, diversity, wild bee

Received: [2017.08.25]

Accepted: [2017.11.10] 